\title{
Association of C/T Polymorphism in the LRP5 Gene with Circulating Follicle Stimulating Hormone in Caucasian Postmenopausal Women
}

\author{
I. ŽOFKOVÁ, M. HILL, K. ZAJÍČKOVÁ \\ Institute of Endocrinology, Prague, Czech Republic
}

Received April 26, 2006

Accepted October 3, 2006

On-line available November 6, 2006

\begin{abstract}
Summary
The LRP5 gene is believed to be primarily associated with bone metabolism via Wnt signaling. The latter pathway, however, appears to control various other systems outside the skeleton. To find the relationships of the LRP5 gene to serum follicle stimulating hormone (FSH) and luteinizing hormone ( $\mathrm{LH})$ in the cohort of normal postmenopausal women, we identified the $C / T$ (c.4037:A1330V) polymorphism in the LRP5 gene using a restriction analysis of the PCR product in a cohort of 165 untreated pre- and post-menopausal women. In a subset of 111 post-menopausal women we analyzed the association between the LRP5 genotype and serum levels of sex-hormones including FSH and LH. The distribution of CC, TC and TT genotypes of the $C / T$ polymorphism in the whole group was $73.9 \%, 23.6 \%$ and $2.4 \%$, respectively, which is comparable with other Caucasian populations. As no TT homozygote was found in the group of post-menopausal women, serum sex-hormones were compared between CC and TC genotypes. Women with the CT allele combination had markedly higher serum FSH levels as compared to carriers of the CC genotype $(p<0.004)$. No differences between these genotypes were found in serum LH levels as well as the circulating sex-steroids such as estradiol, testosterone, dehydroepiandrosterone and/or its sulphate, androstenedione and SHBG. To conclude, the LRP5 gene is associated with circulating FSH in normal post-menopausal women in the present study. The mediating role of subtle undetectable variations in estrogen levels is discussed. We did not find any relationship between the LRP-5 genotype and serum LH levels.
\end{abstract}

Key words

Follicle stimulating hormone - Luteinizing hormone - Sex-steroids - LRP5 gene - C/T (c.4037:A1330V) polymorphism

\section{Introduction}

The low-density lipoprotein receptor-related protein 5 (LRP5) gene on chromosome 11q13 plays a key role in the Wnt canonical pathways, which act as various ligands to stimulate signal transduction (Johnson et al.
2004). It is known that LRP5 is essential for normal morphology, development processes, mechano-sensation and formation of bone ( $\mathrm{Li}$ et al. 2005). The LRP5 gene contributes to normal variations in peak bone mass (Koller et al. 2005) and is associated with the risk of osteoporosis and fractures in elderly women (Bollerslev et al. 2005). 
However, LRP5 is a widely expressed receptor maintaining physiological homeostasis of various other systems. Its central role in binding, endocytosis and degradation of cholesterol-rich lipoproteins is well known (North et al. 2000, Johnson et al. 2004). The LRP5 gene is hypothesized to be a candidate gene for type-1 diabetes (Twells et al. 2003). Furthermore, LRP5 has been implicated in the pathogenesis of some degenerative processes such as malignant diseases (Kuhnen et al. 2000). Associations between candidate genes for osteoporosis and serum sex-hormone levels have been observed in post-menopausal women. This is understood in the context of the common evolution of bone and reproduction (Žofková et al. 2002 a,b,c, 2004). Moreover, Wnt is believed to be one of extrinsic signals arising from the ventral diencephalon and regulating early pituitary development (Asa and Ezzat 2004). The aim of the present study was to analyze the relationship between the additional candidate gene for bone metabolism - the LRP5 and serum sex-hormones in normal post-menopausal women.

\section{Methods}

\section{Subjects}

Genotyping was carried out in 165 untreated preand post-menopausal Caucasian women. Further analysis of serum gonadotropins, sex-steroids and bone density was performed in a subset of 111 postmenopausal women (mean age 62.8 \pm 9.4 years, $13.4 \pm 7.5$ years since menopause).

None of the investigated women had a history of early or late menarche or premature menopause (before 45 years of age). Women with unclear menopausal status were not included in the study. The prior menstrual history of subjects was regular (11-13 cycles/year). The study group did not include any alcoholics, severe smokers, women with psychosis, endocrinopathies or other serious internal diseases. All women gave their informed consent prior to their inclusion in the study. All procedures have been reviewed by the Ethics Committee of the Institute of Endocrinology in Prague.

\section{Protocol}

Blood for measurement of serum follicle stimulating hormone (FSH), luteinizing hormone (LH), sex-steroids and sex hormone binding globulin (SHBG) levels was collected in the morning after overnight fasting.
Samples were stored at $-80^{\circ} \mathrm{C}$ until analyzed.

\section{Analytical methods}

Serum concentrations of FSH (normal postmenopausal range 27-129 U/1) and LH (normal postmenopausal values $>12 \mathrm{U} / \mathrm{l}$ ) were determined by commercial IRMA kits from Immunotech (France) using the Startec analyzer (France) and a monoclonal antibody against biologically and immunologically specific beta sub-unit.

Serum androstenedione was determined using the method described by Putz et al. (1982), unconjugated dehydroepiandrosterone (DHEA) and its sulphate were measured by commercial kits from Immunotech (France). Serum total testosterone levels were estimated by the modified method using $\left[{ }^{125} \mathrm{I}\right]$ tyrosyl methyl ester as a tracer. Serum estradiol was estimated using a commercial kit from Immunotech (France). Duplicate measurements were used to calculate mean values. The inter-assay coefficients of variation were as follows: $6.5 \%$ for $\mathrm{FSH}$, $7.5 \%$ for $\mathrm{LH}, 11.4 \%$ for androstenedione, $11.9 \%$ for DHEA, $10.6 \%$ for DHEA sulphate, $10 \%$ for testosterone and $15 \%$ for estradiol.

\section{Genotyping of LRP5}

The $C / T$ (c.4037:A1330V) polymorphism of the LRP5 gene was determined by a restriction analysis of the PCR product as described by Okubo et al. (2002). A mismatched forward primer (GAC TGT CAG GAC CGC TCA CAC G) introduces a restriction site for DraIII enzyme. We shifted a reverse primer forward to produce a large PCR product for further restriction (AAG GTT TTC AGA GCC CCT AC) (GenBank, accession No. NT 033903). A PCR product of $230 \mathrm{bp}$ was digested with AdeI (Fermentas, Lithuania), an isoschizomere of DraIII, at $37{ }^{\circ} \mathrm{C}$ overnight. After cleavage, the fragments were separated on a $3 \%$ agarose gel. The presence of the AdeI restriction site yielded fragments of 206 and $24 \mathrm{bp}$.

\section{Statistical analysis}

Data are presented as means \pm S.D. After adjustment for the years since menopause, analysis of covariance (ANCOVA) was used to compare quantitative data within the genotypes. Due to non-symmetric data distribution in most of the variables, the original values were transformed by a power transformation to maximum concordance with the Gaussian distribution. In addition, the dependent variables were corrected to symmetric 
Table 1: Hormonal and anthropometrical characteristics of postmenopausal women.

\begin{tabular}{|c|c|c|c|c|c|c|c|}
\hline \multirow{3}{*}{ Variable } & \multicolumn{6}{|c|}{ GENOTYPE } & \multirow{3}{*}{ ANCOVA } \\
\hline & \multicolumn{3}{|c|}{$\mathbf{C C}$} & \multicolumn{3}{|c|}{$\mathbf{C T}$} & \\
\hline & $\mathbf{n}$ & Mean & S.D. & $\mathbf{n}$ & Mean & S.D. & \\
\hline Age (years) & 84 & 62.8 & 9.4 & 27 & 61.6 & 7.5 & ------- \\
\hline YSM (years) & 84 & 13.4 & 8.6 & 27 & 12.9 & 7.8 & ------- \\
\hline$E 2\left(\mathrm{nmol}^{\prime-1} \mathrm{l}^{-1}\right)$ & 84 & 0.088 & 0.108 & 27 & 0.061 & 0.053 & NS \\
\hline$T\left(\mathrm{nmol} \cdot l^{-1}\right)$ & 83 & 1.49 & 0.72 & 27 & 1.50 & 0.76 & NS \\
\hline$D H E A S\left(\mu \mathrm{mol} \cdot l^{-1}\right)$ & 84 & 2.13 & 1.47 & 27 & 2.66 & 1.92 & NS \\
\hline DHEA $\left(\mathrm{nmol} \cdot \mathrm{l}^{-1}\right)$ & 82 & 8.03 & 5.62 & 27 & 8.11 & 4.76 & NS \\
\hline A-dione $\left(\mathrm{nmol} \cdot l^{-1}\right)$ & 83 & 2.35 & 1.45 & 27 & 1.94 & 1.12 & NS \\
\hline$S H B G\left(\right.$ nmol $\left.^{-1} l^{-1}\right)$ & 84 & 61.1 & 29.6 & 26 & 55.2 & 26.2 & NS \\
\hline $\operatorname{IFT}\left(\mathrm{nmol}^{-1} l^{-1}\right)$ & 83 & 3.14 & 2.35 & 26 & 3.83 & 3.70 & NS \\
\hline$F S H\left(U \cdot l^{-1}\right)$ & 81 & 84.7 & 33.0 & 27 & 107.9 & 38.8 & $p<0.004$ \\
\hline$L H\left(U \cdot l^{-1}\right)$ & 82 & 20.0 & 12.9 & 27 & 18.9 & 6.7 & NS \\
\hline
\end{tabular}

YSM-adjusted ANCOVA was used to evaluate the differences between CC and CT genotypes. YSM - years since menopause.

distribution and homoscedasticity of residuals in ANCOVA model. Statistics were performed using the Statgraphics plus v.5.1 software from Manugistics (Rockville, USA).

\section{Results}

The allele frequencies of the $C / T$ (LRP5, c.4037: A1330V) polymorphism in our population were as follows: CC $73.9 \%$, TC $23.6 \%$ and TT $2.4 \%$, which reached the Hardy-Weinberg equilibrium $\left(\chi^{2}=0.1959\right.$, $\mathrm{p} \geq 0.90$ ) and did not differ from other Caucasian populations (Koller et al. 2005, Bollerslev et al. 2005). No TT homozygote was found within the group of 111 post-menopausal women investigated for sex-hormone levels. Thus the data were compared between the $\mathrm{CC}$ and TC genotypes. Higher levels of FSH were observed in women with the $\mathrm{CT}$ genotype compared to $\mathrm{CC}$ homozygotes $(p<0.004)$. Besides adjustment to constant YSM (Table 1), the additional covariate serum estradiol was inserted into the model. In this case, a significant effect of the LRP-5 genotype on serum FSH was confirmed $(p<0.006)$. Finally, unadjusted ANCOVA showed an even higher significance of this relationship. Furthermore, a $9.6 \%$ variation in FSH levels may be explained by the LRP5 genotype. No differences between these genotypes were found in serum LH, sex steroids and their precursors and SHBG (Table 1).

\section{Discussion}

In the present study we showed a strong association between serum FSH levels and $C / T$ polymorphism in the LRP5 gene in untreated postmenopausal women. On the other hand, we found no relationship between the genotype and circulating $\mathrm{LH}$, estradiol, testosterone and/or their precursors.

Physiological production of gonadotropins is primarily encoded by different genes located on chromosomes 6, 11 and 19 (Malmed and Kleinberg 2003). As to FSH, a critical role is played by the FSH beta subunit gene with the AluI element (Du et al. 2002, Hirst et al. 2004). Furthermore, association of serum gonadotropin levels with the calcium-sensing receptor (CaR) gene (intron $5 C / T$ polymorphism) has been shown in postmenopausal women (Žofková et al. 2005).

Wnts are secreted glycoproteins that bind to receptor complexes including LRP5. A subsequent intracellular cascade of events stabilizes beta-catenin, leading to its translocation into the nucleus, where associated with Tcf/Lef transcription factors, it triggers gene expression in target cells (Riwadi and RomanRoman 2005). Although there are no data documenting expression of LRP5 receptors directly in pituitary tissue, the receptor is to a lower extent expressed in the brain (Koay and Brown 2005). This does not exclude the direct association between the LRP5 gene and FSH synthesis. Circulating FSH is a well-known supersensitive indicator 
of sex-steroid homeostasis. Thus, the effect mediated by the primary association between LRP5 and estrogen synthesis cannot be excluded, similarly to the effect of ovarian inhibin A and inhibin B, the disappearance of which is an important predictor of approaching menopause (Overli et al.2005).

Failure to find an association between the LRP5 gene and serum LH levels is explained by the fact that both these gonadotropic systems are mutually independent. Additionally, LH production appears to be controlled separately by specific polymorphisms, such as Trp8Arg, Ile15Thr and Gly102Ser in the LH beta-subunit gene (Lee et al. 2003).

Except for the $C / T$ polymorphism, several other polymorphisms, such as $Q 89 R, N 740 N$ and $A 1330 V$ have been identified in the LRP5 gene (Zhang et al. 2005). Unfortunately, relationships of circulating sex-hormones to these polymorphisms have not been investigated yet.

In conclusion, circulating FSH has been associated with the LRP5 gene in the present study. This finding strengthens the hypothesis that LRP5 is an important pleiotropic mechanism involved in ageing and menopause (Ferrari and Rizzoli 2005). Moreover, it supports the concept of the common evolution of calcium regulating and reproduction systems.

\section{Acknowledgements}

The study was funded by the IGA grant NR/7827-3 from the Ministry of Health of the Czech Republic.

\section{References}

ASA SL, EZZAT S: Molecular basis of pituitary development and cytogenesis. In: Molecular Pathology of the Pituitary. KONTOGEORGOS G, KOVACS K (eds), Karger, Basel 2004, pp 1-19.

BOLLERSLEV J, WILSON SG, DICK IM, ISLAM FM, UELAND T, PALMER L, DEVINE A, PRINCE RL: LRP5 gene polymorphisms predict bone mass and incident fractures in elderly Australian women. Bone 36: 509-606, 2005.

DU LX, LIU SF, YANG YC, JUANY YL: Research on Alu element inserted mutation in porcine FSH beta subunit gene. Yi Chuan Xue Bao 29: 977-982, 2002.

FERRARI SL, RIZZOLI R: Gene variants for osteoporosis and their pleiotropic effects in aging. Mol Aspects Med 26: 145-167, 2005.

HIRST RC, ABEL MH, WILKINS V, SIMPSON C, KNIGHT PG, ZHANG FP, HUHTANIEMI I, KUMAR TR, CHARLTON HM.: Influence of mutations affecting gonadotropin production or responsiveness on expression of inhibin subunit mRNA and protein in the mouse ovary. Reproduction 128: 43-52, 2004.

JOHNSON ML, HARNISH K, NUSSE R, VAN HUL W: LRP5 and Wnt signaling: a union made for bone. $J$ Bone Miner Res 19: 1749-1757, 2004.

KOLLER DI, ISCHIKAWA S, JOHNSON ML, LAI D, XUEI X, EDENBERG HJ: Contribution of the LRP5 gene to normal variation in peak BMD in women. $J$ Bone Miner Res 20: 75-80, 2005.

KOAY MA, BROWN MA: Genetic disorders of the LRP5-Wnt signalling pathway affecting the skeleton. Trends Mol Med 11: 129-137, 2005.

KUHNEN C, HERTER P, MULLER O, MUEHLBERGER T, KRAUSE L, HOMANN H, STEINAU HU, MÜLLER $\mathrm{KM}$ : $\beta$-Catenin in soft tissue sarcomas: expression is related to proliferative activity in high grade sarcomas. Mod Pathol 13: 1005-1013, 2000.

LEE S, KIM NK, KIM HJ, LEE SH, JEONG HJ, CHA KY. Genetic analysis of three polymorphic sites of the luteinizing hormone beta-subunit gene in infertile Korean men with nonobstructive azoospermia. Fertil Steril 79: 517-521, 2003.

LI X, ZHANG Y, KANG H, LIU W, LIU P, ZHANG J, HARRIS SE, WU D: Sclerostin binds to LRP5/6 and antagonizes canonical Wnt signaling. J Biol Chem 280, 19883-19887, 2005.

MALMED S, KLEINBERG D: Anterior pituitary. Development, anatomy and overview of control of hormone secretion. In: Williams Textbook of Endocrinology. LARSEN PR, KRONENBERG HM, MALMED S, POLANSKY KS (eds), Saunders, Philadelphia, 2003, pp 177-279.

NORTH CL, BLACKLOW SC: Evidence that familial hypercholesterolemia mutations of the LDL receptor cause limited local misfolding in an LDL-A module pair. Biochemistry 39: 13127-13135, 2000. 
OKUBO M, HORINISHI A, KIM DH, YAMAMOTO TT, MURASE T: Seven novel sequence variants in the human low density lipoprotein receptor related protein 5 (LRP5) gene. Hum Mutat 19: 186, 2002.

OVERLI I, MORKRID L, ANDERSSON AM, SKAKKEBAEK NE, MOEN MH, HOLTE A: Inhibin A and B as markers of menopause: a five-year prospective longitudinal study of hormonal changes during the menopausal transition. Acta Obstet Gynecol Scand 84: 281-285,2005.

PUTZ Z, HAMPL R, VANUGA A, VELEMINSKY J, STARKA L: A selective radioimmunoassay of androstenedione in plasma and saliva. J Clin Chem Clin Biochem 20: 761-764, 1982.

RIWADI G, ROMAN-ROMAN S: Wnt signalling pathway: a new target for the treatment of osteoporosis. Expert Opin Ther Targets 9: 1063-1077, 2005.

TWELLS RC, MEIN CA, PAYNE F, VEIJOLA R, GILBEY M, BRIGHT M, TIMMS A, NAKAGAWA Y, SNOOK H, NUTLAND S, RANCE HE, CARR P, DUDBRIDGE F, CORDELL HJ, COOPER J, TUOMILEHTOWOLF E, TUOMILEHTO J, PHILLIPS M, METZKER M, HESS JF, TODD JA: Linkage and association mapping of the LRP5 locus on chromosome 11q13 in type 1 diabetes. Hum Genet 113: 99-105, 2003.

ZHANG ZL, QIN YJ, HE JW, HUANG QR, LI M, HU YQ, LIU YJ: Association of polymorphisms in low-density lipoprotein receptor-related protein 5 gene with bone mineral density in postmenopausal Chinese women. Acta Pharmacol Sin 26: 1111-1116, 2005.

ŽOFKOVÁ I, HILL M, ZAJÍČKOVÁ K: Dehydroepiandrosterone status in postmenopausal women is determined by the gene for the vitamin D receptor. Horm Metab Res 34: 127-131, $2002 \mathrm{a}$.

ŽOFKOVÁ I, ZAJÍČKOVÁ K, HILL M: The estrogen receptor alpha gene determines serum androstenedione levels in postmenopausal women. Steroids 67: 815-819, 2002b.

ŽOFKOVÁ I, ZAJÍČKOVÁ K, HILL M, HOŘÍNEK A: Apolipoprotein E gene determines serum testosterone and dehydroepiandrosterone levels in postmenopausal women. Eur J Endocrinol 147: 503-506, 2002c.

ŽOFKOVÁ I, ZAJÍČKOVÁ K, HILL M: Postmenopausal serum androstenedione levels are associated with the calcitonin receptor gene polymorphism T1377C. A pilot study. J Endocrinol Invest 27: 442-444, 2004.

ŽOFKOVÁ I, ZAJÍČKOVÁ K, HILL M, VAŇKOVÁ M: Role of intron 5C/t polymorphism of the calcium sensing receptor gene in the regulation of the serum FSH and LH in postmenopausal women. $J$ Endocrinol Invest 28 : 638-642, 2005.

\section{Corresponding author}

I. Žofková, Institute of Endocrinology, Prague, Czech Republic. E-mail: izofko@endo.cz 